\title{
Large pituitary gland with an expanding lesion in the context of neurofibromatosis 1
}

\author{
Fady Hannah-Shmouni, ${ }^{1}$ Andrew P Demidowich, ${ }^{2}$ Jennifer Rowell, ${ }^{3}$ Maya Lodish, ${ }^{1}$ \\ Constantine A Stratakis ${ }^{1}$
}

\begin{abstract}
'Section on Endocrinology and Genetics, National Institute of Child Health and Human Development, National Institutes of Health, Bethesda, Maryland, USA

${ }^{2}$ Section on Growth and Obesity, National Institute of Child Health and Human Development, National Institute of Health, Bethesda, Maryland, USA

${ }^{3}$ Division of Endocrinology, Metabolism, and Nutrition, Duke University Medical Center, Durham, North Carolina, USA
\end{abstract}

\section{Correspondence to}

Dr Fady Hannah-Shmouni, fady.hannah-shmouni@nih.gov

Accepted 8 September 2017

\section{CrossMark}

To cite: Hannah-Shmouni F, Demidowich AP, Rowell J,

et al. BMJ Case Rep

Published Online First:

[please include Day Month

Year]. doi:10.1136/bcr-2017222411

\section{DESCRIPTION}

A 29-year-old woman with neurofibromatosis 1 (NF1) due to NF1 gene deletion presented for evaluation of long-standing secondary amenorrhea. She noted increasing growth of her hands and feet, inability to fit her ring on her fingers and increasing shoe size coarse and asymmetrical facial features, arthropathy with large hands and feet and multiple café-au-lait lesions. Biochemical evaluation was consistent with growth hormone $(\mathrm{GH})$ and prolactin excess. Pituitary MRI with T1-weighted images showed a voluminous and symmetrically enlarged gland (overall dimensions $15 \times 9 \times 13 \mathrm{~mm}$ ), with a heterogeneous hypointense lesion within the posterior pituitary, measuring $6 \times 6 \times 10 \mathrm{~mm}$ (figure $1 \mathrm{~A}$, arrow). On the fluid-attenuated inversion recovery and T2-weighted images, the lesion was markedly hypointense (not shown). There was no radiographic evidence of optic pathway tumours. Due to both elevations in GH and prolactin, it was decided to treat her acromegaly with cabergoline. A follow-up pituitary MRI was obtained 2 months after initiation of therapy that showed reduction in pituitary size and enlargement of the hypointense lesion (figure 1B). The abnormality within the pituitary is most consistent with a Rathke's cleft cyst, a benign, epithelium-lined intrasellar cyst that is a remnant of the Rathke pouch (arrows). The cyst slightly increased in size following the reduction in pituitary volume from cabergoline therapy. GH excess in patients with NF1 is extremely rare but may be under-recognised. ${ }^{1}$ Indeed, acromegaly most often arises from a single

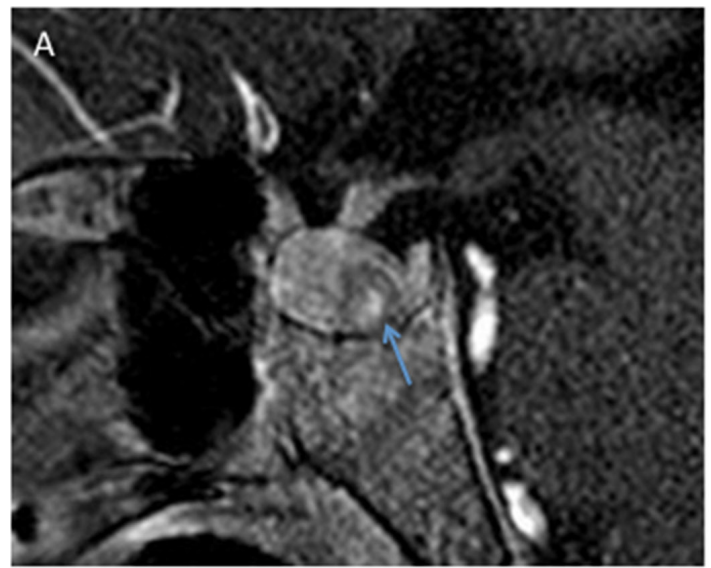
(currently US size 12). Physical examination revealed

GH-secreting pituitary adenoma; however, in certain genetic syndromes that predispose to the development of various tumours, such as NF1 or Carney's complex, generalised mammosomatotroph hyperplasia can be seen, as in this case. ${ }^{2}$ After 2 months of cabergoline therapy, the patient noted a reduction in her ring size.

\section{Learning points}

- A Rathke's cleft cyst is a benign epitheliumlined intrasellar cyst that is a remnant of the Rathke pouch.

- Growth hormone (GH) excess in patients with NF1 is extremely rare and arises from a single GH-secreting pituitary adenoma or generalisedmammosomatotroph hyperplasia.

Contributors All authors participated in the work as a whole and reviewed and agreed with the content of the article.

Competing interests None declared.

Patient consent Obtained.

Provenance and peer review Not commissioned; externally peer reviewed.

(C) BMJ Publishing Group Ltd (unless otherwise stated in the text of the article) 2017. All rights reserved. No commercial use is permitted unless otherwise expressly granted.

\section{REFERENCES}

1 Josefson J, Listernick R, Fangusaro JR, et al. Growth hormone excess in children with neurofibromatosis type 1-associated and sporadic optic pathway tumors. J Pediatr 2011;158:433-6.

2 Moran A, Asa SL, Kovacs K, et al. Gigantism due to pituitary mammosomatotroph hyperplasia. N Engl J Med 1990;323:322-7.

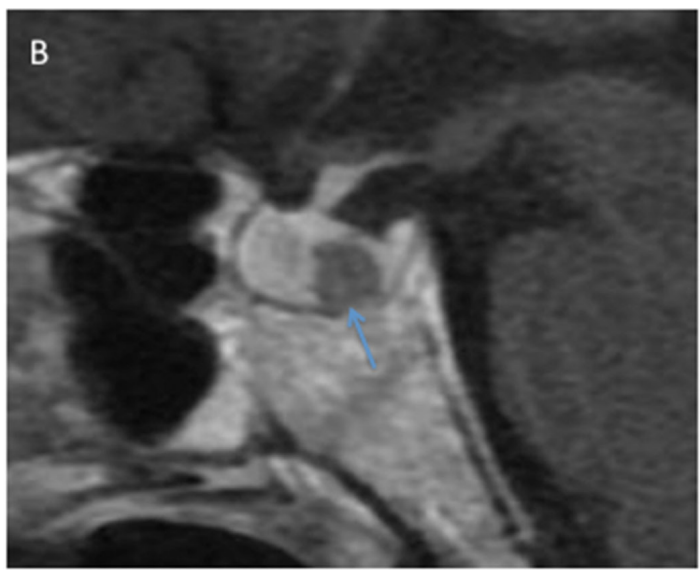

Figure 1 (A) Pituitary MRI with T1-weighted images with contrast showing a voluminous and symmetrically enlarged gland (overall dimensions $15 \times 9 \times 13 \mathrm{~mm}$ ), with a hypointense lesion within the posterior pituitary, measuring $6 \times 6 \times 10 \mathrm{~mm}$ (figure 1A, arrow). (B) Follow-up pituitary MRI with T1-weighted images with contrast on a different machine was obtained 2 months after initiation of cabergoline therapy showing a reduction in pituitary size (overall dimensions $12 \times 8 \times 10 \mathrm{~mm}$ ) and enlargement of the hypointense lesion measuring $9 \times 9 \times 12 \mathrm{~mm}$. 
Copyright 2017 BMJ Publishing Group. All rights reserved. For permission to reuse any of this content visit http://group.bmj.com/group/rights-licensing/permissions.

BMJ Case Report Fellows may re-use this article for personal use and teaching without any further permission.

Become a Fellow of BMJ Case Reports today and you can:

- Submit as many cases as you like

- Enjoy fast sympathetic peer review and rapid publication of accepted articles

Access all the published articles

- Re-use any of the published material for personal use and teaching without further permission

For information on Institutional Fellowships contact consortiasales@bmjgroup.com

Visit casereports.bmj.com for more articles like this and to become a Fellow 